\title{
Biotransfer of cobalt along a soil-plant- chicken food chain: Implication for public health
}

\author{
Zill-E-Huma ${ }^{1}$, Zafar Iqbal Khan ${ }^{1 *}$, Ijaz Rasool Noorka ${ }^{2}$, Kafeel \\ Ahmad $^{1}$, Muhammad Nadeem ${ }^{3}$ and Ilker Ugulu ${ }^{4}$ \\ 1. Department of Botany, University of Sargodha, Sargodha-Pakistan \\ 2. Agriculture College, University of Sargodha, Sargodha-Pakistan \\ 3. Institute of Food Science and Nutrition, University of Sargodha-Pakistan \\ 4. Faculty of Education, Usak University, Usak-Turkey \\ *Corresponding author's email:zafar.khan@uos.edu.pk \\ Citation \\ Zill-E-Huma, Zafar Iqbal Khan, Ijaz Rasool Noorka, Kafeel Ahmad, Muhammad Nadeem and Ilker Ugulu. \\ Biotransfer of cobalt along a soil-plant-chicken food chain: Implication for public health. Pure and Applied \\ Biology. Vol. 8, Issue 3, pp2015-2027. http://dx.doi.org/10.19045/bspab.2019.80146
}

\begin{tabular}{llll}
\hline \hline Received: 15/05/2019 & Revised: 10/07/2019 & Accepted: 16/07/2019 & Online First: 24/07/2019 \\
\hline \hline
\end{tabular}

\section{Abstract}

This study was carried out for the determination of cobalt (Co) accumulation in four varieties of maize (grains, shoot and root) and in seven tissues of chickens (blood, bone, breast meat, kidney, liver, heart and gizzard) using wet digestion method by atomic absorption spectrophotometer. Representative samples of water, soil, grains and different chicken parts were assayed for Co contents. Compared to canal and ground water, sewage water had the highest concentration of $\mathrm{Co}$, which is the reason why the maize plants irrigated with sewage water had the highest Co concentration. The group of chickens that were reared with grains treated by sewage water treated grains also showed the highest Co concentration in their body parts compared to the other groups. Enrichment factor and pollution load index for the soil, as well as bioconcentration, bioaccumulation and transfer factors were assessed to evaluate the transfer of Co from water to soil and to the plant. Target Hazard Quotient (THQ) was also calculated to estimate the potential human health risk of Co contamination from consumption of selected chicken parts (liver, breast meat and gizzard) by the local inhabitants and found the THQ values <1. THQ values for Co were less than 1.0 for meat, liver and gizzard which indicated that the exposed population was unlikely to experience obvious adverse effects on utilization of these poultry edibles.

Keywords: Biomonitoring, heavy metal, health risk

\section{Introduction}

Heavy metals as a general collective term are a group of elements with atomic density greater than $4 \mathrm{~g} / \mathrm{cm}^{3}$ or five times or greater than water, which tend to release electrons in chemical reactions and form simple cations [1, 2]. In the living systems, heavy metals play a vital role in the biological processes till their concentration does not exceed the required limits because in the elevated concentrations heavy metals are injurious to health [3-5]. With long nonbiodegradable nature, the heavy metals could remain persistent in the environment for a long time $[6,7]$. Superfluous effects are caused to various body parts by heavy metals as they tend to accumulate in body due to their long biological half-lives [8]. Heavy metals are found in soil naturally [9]. Toxic percentages of heavy metals are 
released into environment by anthropogenic and geologic activities. These activities include utilization of pesticides and fertilizers in agriculture, mining, fossil fuel burning, smelting process of metals, batteries production and production of different metals in sewage sludge, industries, and public waste disposal [10-12]. Incessant irrigation with wastewater, results in accumulation of heavy metals in the soil, which ultimately affects the development of plant [13]. As the soils are easily exchanged and reached, humans are subjected to direct effect on health via pollution of soils [14]. Soils act as poisonous chemical channel may accumulate heavy metals from wastewater. Because of continuous absorption of toxins and changes in $\mathrm{pH}$, the limit of soils to hold toxic metals being decreased accordingly soil may discharge heavy metals into groundwater or accessible for plant uptake [15]. The ability of heavy metals to assimilate in living system and then entering the food chain is the main reason behind their toxic nature $[16,17]$. Food chain contamination is the consequence of wastewater irrigation through which heavy metals enter into human body. Heavy metal accumulation causes various disorders in the human body and moreover these metals (even in fewer amounts) could cause mental disorders in children [18].

Nowadays, the escalating insists of food safety has encouraged the research concerning the danger allied with the utilization of food stuffs contaminated with heavy metals and/or toxins [19]. Improvements in the food production and processing technology had increased the chances of contamination of food with various environmental pollutants, especially heavy metals. Ingestion of these contaminants by animals causes deposition of residues in meat [20]. Environmental contaminants are usually concentrated in the tissues of chickens which can be used to guesstimate the enduring or acute exposure, as chickens are fed an ample variety of feed stocks [21]. Through the utilization of contaminated diets, the metals are accumulated in chickens have been studied in a few to assess the potential human risk from poultry consumption [22].

In the present study, we investigated the effect of short-term use of sewage, canal and groundwater on the cobalt accumulation in maize and in experimental chickens which were fed on grains obtained from the experimental maize. The main objective of this study was to evaluate the level of heavy metals along soil-plant and animal. Another objective of the current research was to estimate the target hazard quotient to evaluate whether experimental chicken parts are safe for human consumption or not.

\section{Materials and methods Study site}

A soil culture experiment was planted in plastic bags carried out in the wirehouse, University College of Agriculture, University of Sargodha.

\section{Sample preparation}

Seeds were collected from country leading Maize and Millet Research Institute (CMRI) Yousaf wala, Sahiwal, Pakistan including Pearl (white), Sahiwal-2002 (yellow), MMRI (yellow), Sadaf (white).

The experimental project was carried out using CRD (Completely Randomized Design) comprising three replication and three water regimes (ground water, sewage water and canal water). The sources of water remained a viable variable.

Soil bags containing $20 \mathrm{~kg}$ of sandy loam soil was used in the experiment. The field capacity was measured by volumetric means and 2 liters water of each treatment was used to irrigate the soil bags since sowing to the harvesting. The soil analysis was made before bag filling and each source of water analysis was made before the initiation of the study and found buffer for any metal in it. Two experiments were conducted in varying seasons that is Experiment 1 in Spring season and Experiment 2 in Autumn season.

The four seeds were sown in each bag and at three-leaf stage two weak seedlings were 
uprooted for ample space of remaining seedlings. All standard agronomic practices were in use for good crop stand and stay green for potential yield corn. At maturity, the crop was harvested, the grains were separated from each cob. $10 \mathrm{~g}$ sample of grains, plant root, plant stem and plant leaves were subjected for metal analysis and the remaining's were used as feed for the experimental chickens.

The next phase of the experiment is to the transfer of metal from grains to animal. To check the metal transfer translocation ratio the 2 days old domestic chickens (Missouri golden) breed were purchased from the hatchery in Sargodha. A small cage was made according to the requirement of the chicken. Two chickens were separately allocated, and feed made by the corn grains obtained by three treatments with respect to water was given. The chickens were fed on grind corn grains (variable factors) mixed with standard chicken feed (constant factor) until 45 days of age/maturity. The chickens were then slaughtered to check the metal translocation and their body parts (blood, bone, breast meat, liver, heart, kidney and gizzard) were taken for the evaluation of transfer of cobalt from corn to chickens using wet digestion method.

\section{Digestion}

Water samples, used for irrigation, were digested by using the method of Radojevic and Bashkin [23]. Soil samples were taken out from oven after five days and digested by wet digestion method delineated by Vukadinovic and Bertic [24]. To determine the concentration of Co in each part of corn plant (root, stem, leaf and seed), representative $10 \mathrm{~g}$ samples were taken and analyzed by using the method delineated by Anar et al. [25]. Chicken samples were prepared separately for analysis by adopting the method designed by Mohammed et al. [26] except the blood which was digested by the method as given by the Memon et al. [27].

\section{Analysis}

After digestion, all the samples were analyzed for cobalt by atomic absorption spectrophotometer (AA 6300 Shimadzu Japan) with graphite furnace and Zeeman background corrector was used to determine soils and forage Co concentrations. SPSS version 13 was used for statistical analysis. The experiment will be carried out in completely randomized design. The differences between the mean concentration values were found at $p>0.05$ (non-significant); $\quad p<0.05$ (Significant); highly significant $(p<0.01)$ probability levels.

Target hazard quotient (THQ) was also calculated using the following equation [28].

$\mathrm{THQ}=(\mathrm{EF} \times \mathrm{ED} \times \mathrm{FIR} \times \mathrm{C} / \mathrm{RfD} \times \mathrm{BW} \times \mathrm{AT})$ $\times 10^{-3}$

where $\mathrm{EF}$ is the exposure frequency, ED is the exposure duration, FIR is the food ingestion rate and in the present study, chicken tissues ingestion rate was assumed to be $32.7 \mathrm{~g} /$ person/day, $\mathrm{C}$ is the metal concentration in tissues of chicken $(\mathrm{mg} / \mathrm{kg}$ dry weight); RfD is the oral reference dose for metal, BW is the average consumer body weight $(70 \mathrm{~kg})$ and TA is the average exposure time for non-carcinogens (365 day/year $\times \mathrm{ED}$ ).

\section{Quality control analysis}

To avoid any infectivity standards were prepared carefully. Measurement of soil and vegetable samples was done on the basis of dry weight. Analyses were performed three times for each sample. Quality control procedures were strictly followed for the entire sample to ensure the quality of results.

\section{Results}

\section{The concentration of cobalt in water}

Analysis of variance of data for Co concentration is shown in (Table 1) which indicated that in all sources of water, there was a non-significant difference in $\mathrm{Co}$ concentration. The concentration of Co was high in sewage water compared to other water samples used for irrigation (Table 1; Figure 1). 
Table 1. Analysis of variance for cobalt in ground, sewage and canal water

\begin{tabular}{|c|c|c|}
\hline \multicolumn{3}{|c|}{ Mean squares } \\
\hline Source of variation (SOV) & Degree of freedom (df) & Cobalt \\
\hline Source & 2 & $0.0037^{\text {ns }}$ \\
\hline Error & 6 & 0.0107 \\
\hline
\end{tabular}

ns $=$ Non-significant $(\mathrm{P}>0.05) ; *=$ Significant $(\mathrm{P}<0.05) ; * *=$ Highly significant $(\mathrm{P}<0.01)$

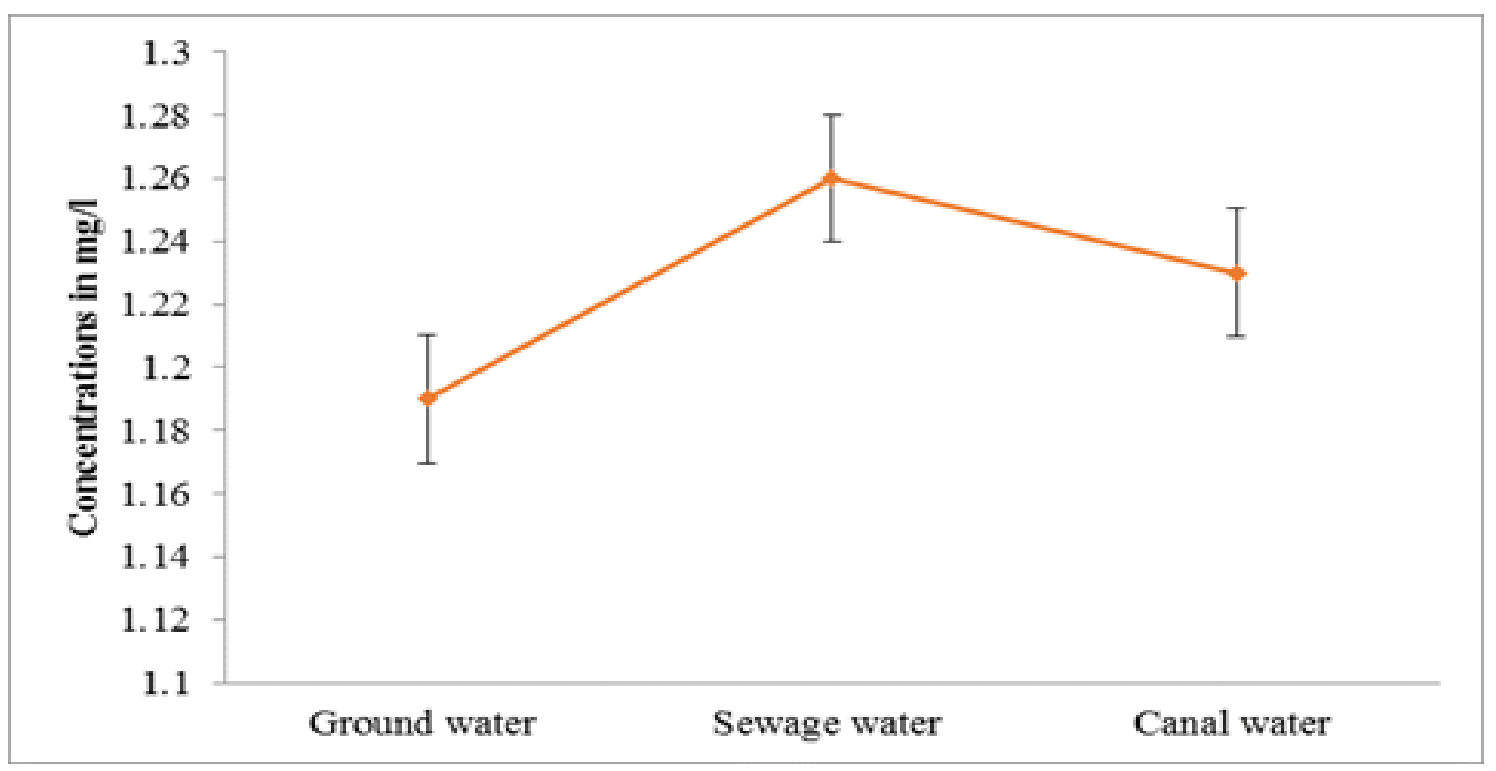

Figure 1. The concentration of cobalt in water used in experiments

\section{The concentration of cobalt in soil}

Analysis of variance of data for Co concentration in soil showed that there was a significant difference in Co concentration in both seasons. The concentration of $\mathrm{Co}$ was high in sewage water irrigated soil compared to ground water and canal water irrigated soil samples (Table 2; Figure 2).
The concentration of cobalt in plant samples

Analysis of variance of data for $\mathrm{Co}$ in grains, shoot and root is shown in Table 3, indicated that season variety and treatment significantly affected the concentration of Co in all parts of the plant. Season $x$ Treatment, Variety $\times$ Treatment, Season $x$ Variety $\times$ Treatment interactions were nonsignificant in all parts of the plant except Season $\times$ Variety interaction was only nonsignificant in the shoot (Table 3 ).

Table 2. Analysis of variance for cobalt in soil $(\mathrm{mg} / \mathrm{kg})$ irrigated with ground, sewage and canal water

\begin{tabular}{|c|c|c|c|}
\hline \multicolumn{4}{|c|}{ Mean Squares } \\
\hline Source of variation & Degree of & Experiment 1 & Experiment 2 \\
\hline (SOV) & freedom (df) & (Spring season) & (Autumn season) \\
\hline Source & 2 & & $0.0477^{* *}$ \\
\hline Error & 6 & $0.7214^{*}$ & 0.0006 \\
\hline
\end{tabular}

ns $=$ Non-significant $(\mathrm{P}>0.05) ; *=$ Significant $(\mathrm{P}<0.05) ; * *=$ Highly significant $(\mathrm{P}<0.01)$ 


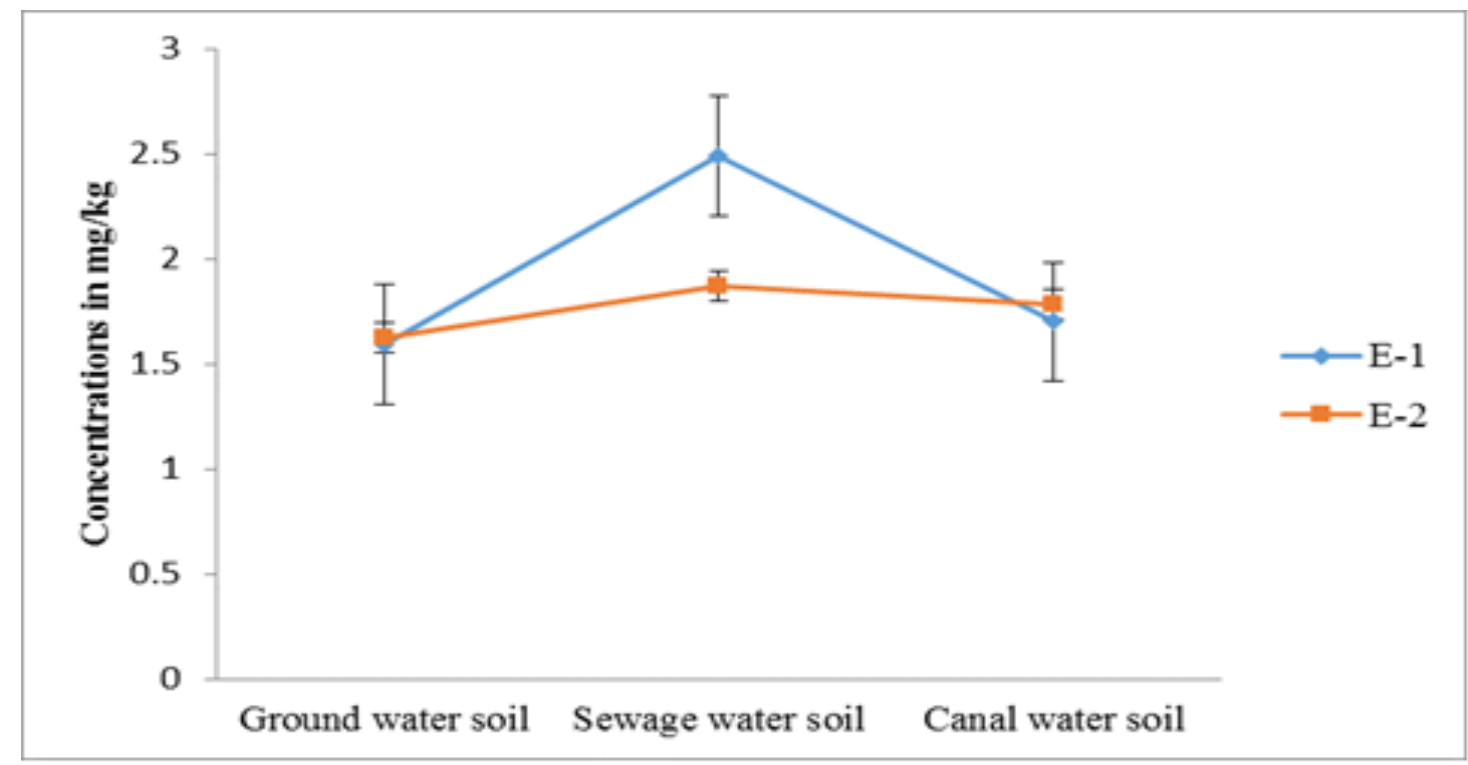

Figure 2. The concentration of cobalt in soil in two experiments

Table 3. Analysis of variance (Mean squares) of data for grains, shoot and root of four varieties of corn differing in concentrations of cobalt grown in pots under diverse irrigations (ground water, sewage water and canal water) in both experiments conducted in varying seasons

\begin{tabular}{|c|c|c|c|c|}
\hline \multicolumn{5}{|c|}{ Mean squares } \\
\hline $\begin{array}{c}\text { Source of Variation } \\
\text { (SOV) }\end{array}$ & $\begin{array}{c}\text { Degree of } \\
\text { freedom (df) }\end{array}$ & Grains & Shoot & Root \\
\hline Season & 1 & $1.5167^{* *}$ & $0.3850^{* *}$ & $2.7907^{* *}$ \\
\hline Variety & 3 & $0.4222^{* *}$ & $0.2369^{* *}$ & $0.2287^{* *}$ \\
\hline Treatment & 2 & $0.0401^{* *}$ & $0.0407^{* *}$ & $0.0459^{* *}$ \\
\hline & & & & $0.0661^{* *}$ \\
\hline SxV & 3 & $0.1934^{* *}$ & $0.0139 \mathrm{~ns}$ & \\
\hline SxT & 2 & $0.0030 \mathrm{~ns}$ & $0.0026 \mathrm{~ns}$ & $0.0058 \mathrm{~ns}$ \\
\hline VxT & 6 & $0.0064 \mathrm{~ns}$ & $0.0009 \mathrm{~ns}$ & $0.0042 \mathrm{~ns}$ \\
\hline SxVxT & 6 & $0.0022 \mathrm{~ns}$ & $0.0020 \mathrm{~ns}$ & $0.0028 \mathrm{~ns}$ \\
\hline Error & 48 & 0.0034 & 0.0058 & 0.0056 \\
\hline
\end{tabular}

$\mathrm{ns}=$ Non-significant $(\mathrm{P}>0.05) ; *=$ Significant $(\mathrm{P}<0.05) ; * *=$ Highly significant $(\mathrm{P}<0.01) ; \mathrm{S}$, Seasons; V, variety; $\mathrm{T}$, treatment, $\mathrm{S} \times \mathrm{V}$, season into variety interaction; $\mathrm{S} \times \mathrm{T}$, season into treatment interaction; $\mathrm{V} \times \mathrm{T}$, Variety into treatment interaction; $\mathrm{S} \times \mathrm{V} \times \mathrm{T}$, season into variety into treatment interaction

In both seasons, the highest concentration of $\mathrm{Co}$ (E-1, 0.82 \pm 0.05 ; Experiment 2 (Autumn season), $0.84 \pm 0.06$ ) was found in grains of Sadaf variety at sewage water treatment and the lowest (Experiment 1 (Spring season), 0.63 \pm 0.03 ; Experiment 2 
(Autumn season), $0.17 \pm 0.04$ ) was found in grains of MMRI variety at groundwater treatment (Figure 3).

In experiment 1 (Spring season), the highest level of $\mathrm{Co}$ for the shoot $(1.13 \pm 0.02)$ was found in Sadaf variety at sewage water treatment and the lowest concentration of Co $(0.79 \pm 0.05)$ was found in the shoot of Pearl variety at ground water treatment. In experiment 2 (Autumn season), the maximum level of Co $(1.25 \pm 0.08)$ was found in the shoot of Sadaf variety at sewage water treatment and canal water treatment and the minimum concentration of $\mathrm{Co}(0.06 \pm 0.00)$ was found in Pearl variety at groundwater treatment (Figure 3).

In Experiment 1 (Spring season), the highest level of Co for root $(1.34 \pm 0.08)$ was found in Sadaf variety at sewage water treatment and the lowest concentration of Co $(1.06 \pm 0.02)$ was found in the root of Pearl variety at groundwater treatment. In Experiment 2 (Autumn season), the maximum level of Co $(1.78 \pm 0.01)$ was found in the root of Sadaf variety at sewage water treatment and the minimum $(1.35 \pm 0.04)$ concentration of Co $(0.06 \pm 0.00)$ was found in Pearl variety at groundwater treatment (Figure 3 ).

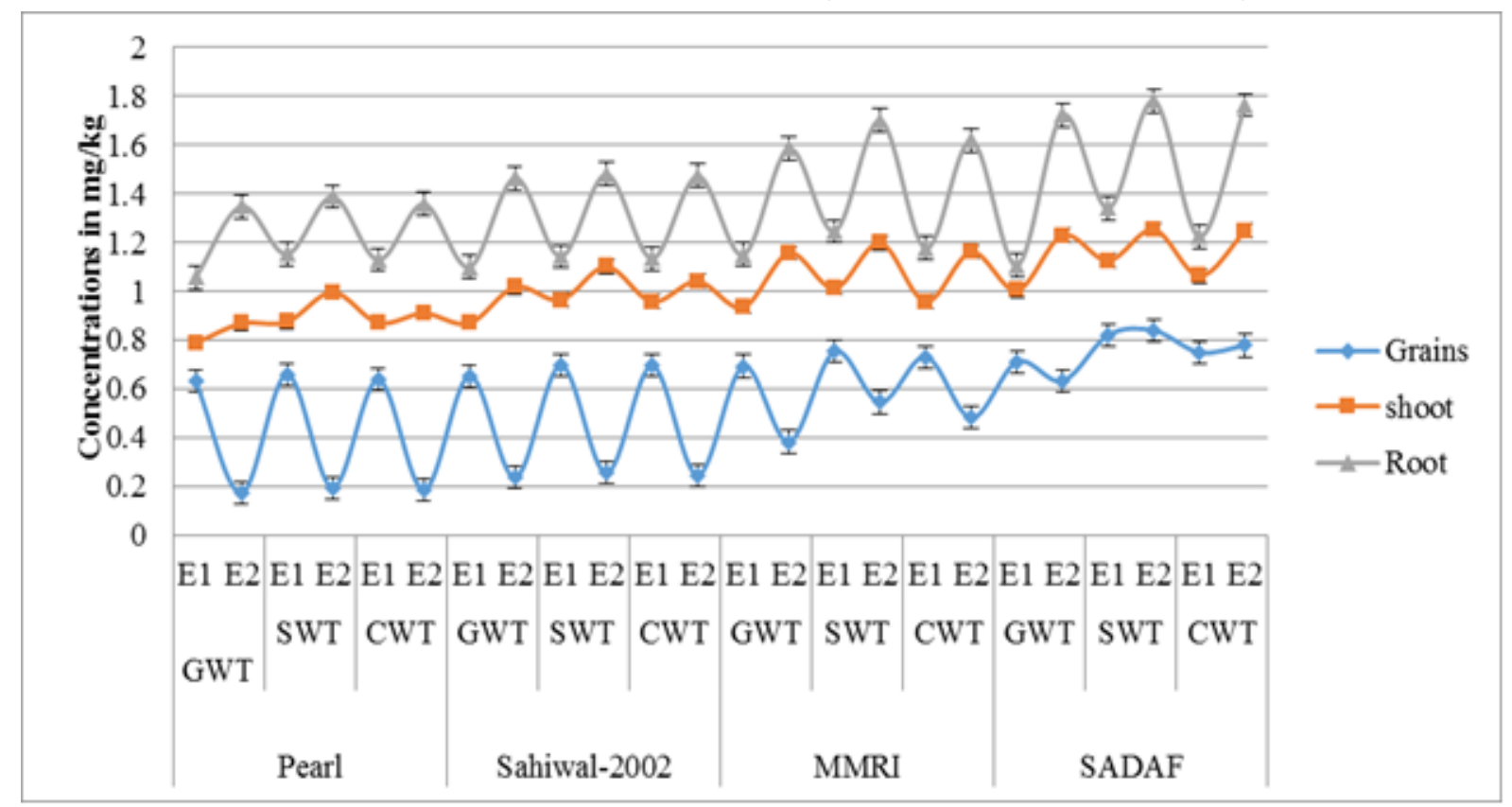

Figure 3. The concentration of cobalt in plant parts (Shoot, Root and Grains) in two experiments

\section{Concentration of cobalt in chickens}

Analysis of variance of data for cobalt in various body parts of chickens was shown in (Table 4), indicating that seasons significantly affected the concentration of Co in all body parts. Varieties nonsignificantly affected the Co concentration only in blood and heart whereas treatment significantly affected the Co concentration in all parts of chicken except kidney and gizzard. Season $\times$ Variety interaction was significant only in meat and heart. On the other hand, Season $\times$ Treatment, Variety $\times$ Treatment and Season $x$ Variety $\times$
Treatment interaction were significant only in bone (Table 4).

The maximum concentration of Co in blood during Experiment 1 (Spring season) $(2.22 \pm 0.07)$ was in chickens that used grains of Sadaf Variety raised with sewage water in their diet and the minimum level was found in blood $(1.79 \pm 0.02)$ of the chickens that used grains of Pearl Variety raised with ground and canal water in their diet. In Experiment 2 (Autumn season) the highest concentration of Co was found in the blood $(3.09 \pm 0.21)$ of chickens that utilized grains of Pearl Variety raised with 
sewage water in their diet and the lowest $(2.13 \pm 0.16)$ was found on the utilization of the grains of MMRI Variety raised with groundwater (Figure 4).

The maximum concentration of Co in bone during Experiment 1 (Spring Season) $(2.78 \pm 0.03)$ was in chickens that used grains of Sadaf variety raised with sewage water in their diet and the minimum level was found in bone $(2.22 \pm 0.02)$ of the chickens that used grains of Sahiwal-2002 variety raised with groundwater in their diet. In Experiment 2 (Autumn Season), the highest concentration of Co was found in the bone $(2.03 \pm 0.30)$ of chickens that utilized grains of Pearl variety raised with sewage water in their diet and the lowest $(0.07 \pm 0.03)$ was found on the utilization of the grains of Sahiwal-2002 variety raised with groundwater (Figure 4).

The maximum concentration of $\mathrm{Co}$ in meat during Experiment 1 (Spring Season) $(3.60 \pm 0.28)$ was in chickens that used grains of Sadaf variety raised with sewage water in their diet and the minimum level was found in meat $(2.90 \pm 0.04)$ of the chickens that used grains of Pearl variety raised with groundwater in their diet. In Experiment 2 (Autumn Season), the highest concentration of Co was found in the meat $(0.77 \pm 0.04)$ of chickens that utilized grains of Sadaf variety raised with sewage water in their diet and the lowest $(0.26 \pm 0.07)$ was found on the utilization of the grains of Pearl variety raised with groundwater (Figure 4).

The maximum concentration of $\mathrm{Co}$ in the liver during Experiment 1 (Spring Season) $(4.15 \pm 0.03)$ was in chickens that used grains of MMRI variety raised with sewage water in their diet and the minimum level was found in liver $(3.46 \pm 0.04)$ of the chickens that used grains of Pearl variety raised with groundwater in their diet. In Experiment 2 (Autumn Season), the highest concentration of Co was found in the liver $(1.11 \pm 0.02)$ of chickens that utilized Sadaf variety grains raised with sewage water in their diet and the lowest $(0.66 \pm 0.04)$ was found on the utilization of the grains of
Pearl variety raised with groundwater (Figure 4).

The maximum concentration of Co in heart during Experiment 1 (Spring Season) $(4.33 \pm 0.02)$ was in chickens that used grains of Pearl variety raised with sewage water in their diet and the minimum level was found in heart $(3.82 \pm 0.07)$ of the chickens that used grains of Pearl variety raised with groundwater in their diet. In Experiment 2 (Autumn Season), the highest concentration of Co was found in the heart (1.26 \pm 0.05$)$ of chickens that utilized Sadaf variety grains rose with sewage water in their diet and the lowest $(1.02 \pm 0.04)$ was found on the utilization of the grains of Pearl variety raised with groundwater (Figure 4).

The maximum concentration of $\mathrm{Co}$ in kidney during Experiment 1 (Spring Season) (4.09 \pm 0.13$)$ was in chickens that used grains of Pearl variety raised with sewage water in their diet and the minimum level was found in kidney (3.52 \pm 0.14$)$ of the chickens that used grains of Sadaf variety raised with groundwater in their diet. In Experiment 2 (Autumn Season), the highest concentration of Co was found in the kidney $(1.41 \pm 0.02)$ of chickens that utilized grains of Sadaf variety raised with sewage water in their diet and the lowest $(1.14 \pm 0.02)$ was found on the utilization of the grains of Pearl variety raised with groundwater (Figure 4).

The maximum concentration of $\mathrm{Co}$ in gizzard during Experiment 1 (Spring Season) (3.63 \pm 0.09$)$ was in chickens that used grains of Sahiwal-2002 variety raised with sewage water in their diet and the minimum level was found in gizzard $(2.42 \pm 0.29)$ of the chickens that used grains of Sadaf variety raised with groundwater in their diet. In Experiment 2 (Autumn Season), the highest concentration of Co was found in the gizzard $(1.60 \pm 0.07)$ of chickens that utilized grains of Sahiwal2002 variety raised with sewage water in their diet and the lowest $(1.51 \pm 0.02)$ was found on the utilization of the grains of 
Sahiwal-2002 variety raised with groundwater (Figure 4).

Table 4. Analysis of variance (Mean squares) of data for grains, shoot and root of four varieties of corn differing in concentrations of cobalt grown in pots under diverse irrigation (ground water, sewage water and canal water) in both experiments conducted in varying seasons

\begin{tabular}{|c|c|r|r|r|r|r|r|c|}
\hline \multicolumn{9}{|c|}{ Mean squares } \\
\hline $\begin{array}{c}\text { Sources of } \\
\text { Variation } \\
(\text { SOV) }\end{array}$ & $\begin{array}{c}\text { Degree of } \\
\text { freedom } \\
\text { (df) }\end{array}$ & Blood & Bone & Meat & Liver & Heart & Kidney & Gizzard \\
\hline Season & 1 & $3.6658^{* *}$ & $53.833^{* *}$ & $88.319^{* *}$ & $108.420^{* *}$ & $105.658^{* *}$ & $72.595^{* *}$ & $26.9251^{* *}$ \\
\hline & & & & & & & & \\
\hline Variety & 3 & $0.0159 \mathrm{~ns}$ & $0.5064^{* *}$ & $0.4992^{* *}$ & $0.4672^{* *}$ & $0.0380 \mathrm{~ns}$ & $0.1255^{*}$ & $0.5395^{* *}$ \\
\hline & & & & & & & & \\
\hline Treatment & 2 & $0.2104^{*}$ & $0.4544^{* *}$ & $0.0767^{* *}$ & $0.0994^{* *}$ & $0.1980^{* *}$ & $0.0379 \mathrm{~ns}$ & $0.0123 \mathrm{~ns}$ \\
\hline & & & & & & & & \\
\hline $\mathrm{S} \times \mathrm{V}$ & 3 & $0.3645^{* *}$ & $0.9188^{* *}$ & $0.0176 \mathrm{~ns}$ & $0.0620^{* *}$ & $0.0257 \mathrm{~ns}$ & $0.3067 * *$ & $0.7267 * *$ \\
\hline & & & & & & & & \\
\hline $\mathrm{S} \times \mathrm{T}$ & 2 & $0.0961 \mathrm{~ns}$ & $0.1192^{*}$ & $0.0008 \mathrm{~ns}$ & $0.0153 \mathrm{~ns}$ & $0.0546 \mathrm{~ns}$ & $0.0070 \mathrm{~ns}$ & $0.0289 \mathrm{~ns}$ \\
\hline & & & & & & & & \\
\hline $\mathrm{V} \times \mathrm{T}$ & 6 & $0.0124 \mathrm{~ns}$ & $0.1899^{* *}$ & $0.0068 \mathrm{~ns}$ & $0.0059 \mathrm{~ns}$ & $0.0080 \mathrm{~ns}$ & $0.0070 \mathrm{~ns}$ & $0.1259 \mathrm{~ns}$ \\
\hline & & & & & & & & \\
\hline $\mathrm{S} \times \mathrm{V} \times \mathrm{T}$ & 6 & $0.0111 \mathrm{~ns}$ & $0.2523^{* *}$ & $0.0009 \mathrm{~ns}$ & $0.0023 \mathrm{~ns}$ & $0.0096 \mathrm{~ns}$ & $0.0092 \mathrm{~ns}$ & $0.1035 \mathrm{~ns}$ \\
\hline & & & & & & & & \\
\hline Error & 24 & 0.0391 & 0.0221 & 0.0133 & 0.0051 & 0.0332 & 0.0390 & 0.0902 \\
\hline
\end{tabular}

ns = Non-significant $(\mathrm{P}>0.05) ; *=$ Significant $(\mathrm{P}<0.05) ; * *=$ Highly significant $(\mathrm{P}<0.01) ; \mathrm{S}$, Seasons; V, variety; $\mathrm{T}$, treatment, $\mathrm{S} \times \mathrm{V}$, season into variety interaction; $\mathrm{S} \times \mathrm{T}$, season into treatment interaction; $\mathrm{V} \times \mathrm{T}$, Variety into treatment interaction; $\mathrm{S} \times \mathrm{V} \times \mathrm{T}$, season into variety into treatment interaction

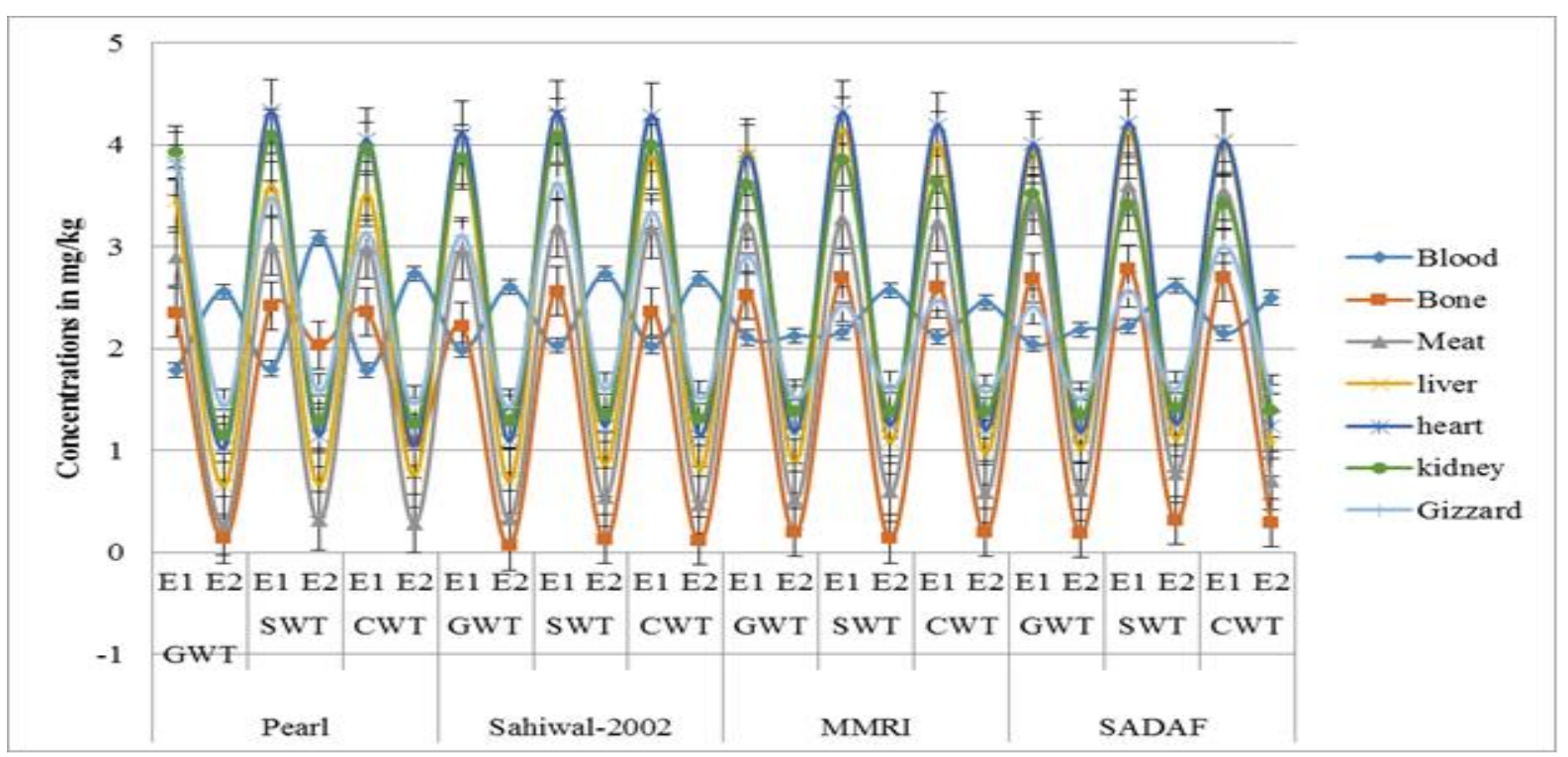

Figure 4. The concentration of cobalt in body parts of chickens in two experiments

\section{Discussion}

In the present study, we aimed to evaluate accumulation and translocation of Co along soil-plant and animal. The maximum permissible limit of Co in water according to $\mathrm{WHO}$ is $0.005 \mathrm{mg} / \mathrm{L}$ [9]. In the current research, all water samples contained $\mathrm{Co}$ above its safe limit. However, sewage 
water showed the highest concentration of Co followed by canal water and ground water respectively. This result was in line with Al-Omran [29] who found that sewage effluent contained much higher amounts of $\mathrm{Co}, \mathrm{Cu}, \mathrm{Fe}, \mathrm{Mn}, \mathrm{Cr}, \mathrm{Pb}$ and $\mathrm{Ni}$ compared to ground well water. Sewage water irrigation is also known to contribute significantly to the heavy metal content of soils [15]. The long-term application of treated and untreated wastewater has resulted in a significant build-up of heavy metals in the soil [13]. Sewage effluents are usually considered a prosperous source of other nutrients and organic matter, but they increased the levels of heavy metals, such as $\mathrm{Mn}, \mathrm{Fe}, \mathrm{Co}, \mathrm{Cu}, \mathrm{Pb}, \mathrm{Ni}, \mathrm{Cr}, \mathrm{Co}$ and $\mathrm{Cd}$ in the soils irrigated with sewage water [9]. The present research also showed the highest concentration of $\mathrm{Co}$ in soil irrigated with sewage water compared to canal and ground water irrigated soils (Figure 5). Results were in line with Shad et al. [30] also found a higher concentration of Co in soil irrigated with sewage water than those irrigated with canal water. The concentration of $\mathrm{Co}$ in all soil samples were in safe limits that are $65 \mathrm{mg} / \mathrm{kg}$ [31].

In the current research, the roots showed the highest concentration of Co than shoot and the least value was shown by the grains in both seasons by all varieties same was reported by Mojiri and Hamidi [32]. They found higher concentrations of heavy metals in wheat plants treated with municipal wastewater and also observed more accumulation of metals in roots than in shoots. In the present research, sewage irrigated plant parts showed a higher concentration of Co compared to other treatments which were may be due to the presence of a higher concentration of Co in wastewater. Jayakumar and Jaleel [33] conducted a study based on exogenous Co in soybean. In his experiment, they treated soybean with different levels of Co (50, $100,150,200$ and $250 \mathrm{mg} \mathrm{kg}$ ) and found the highest concentration of Co in leaves, stem, seeds and root treated with $250 \mathrm{mg} / \mathrm{kg}$ Co and the least were observed in control.
Many studies have indicated that crops grown in metal-contaminated soil have higher concentrations of metals than those in uncontaminated soil [13]. Hussain et al. [34] conducted an experiment and found the higher concentration of heavy metals including $\mathrm{Co}$ in wastewater treated Brassica napus and Lactuca sativa compared to control. Shad et al. [30] found the higher concentration of Co in the shoot of wheat plants irrigated with sewage water compared to canal water irrigated plants. However, in their research grains from the wheat plants irrigated with sewage water accumulated the less amount of Co which was contrary to the results of the present research. Tremendous accumulation of heavy metals in agricultural soils in the course of wastewater irrigation may not only result in soil pollution but also lead to more heavy metal up-take by crops, affecting food quality and as well as food safety [13]. Brar et al. [35] also reported higher accumulation of metals in leaves and tubers of potato grown on sewage irrigated soils as compared with ground water irrigated soils. According to FAO/WHO the maximum permissible limit of $\mathrm{Co}$ in grains was $50 \mathrm{mg} / \mathrm{kg}$ and all the grains were within safe limit [36].

Various studies were conducted to evaluate the heavy metal concentration in plants. Amin et al. [37] studied the accumulation of various heavy metals $(\mathrm{Cu}, \mathrm{Ni}, \mathrm{Co}, \mathrm{Cr}, \mathrm{Fe}$, $\mathrm{Mn}, \mathrm{Co}$ and $\mathrm{Pb}$ ) in green vegetables like Allium sativum, Allium cepa, Solanum lycopersicum and Solanum melongena, irrigated with wastewater in Mardan, Pakistan. Their study showed that heavy metals in vegetable grown on soil irrigated with wastewater were considerably higher compared to those of tube well water irrigated soil.

Similarly, Odai et al. [38] studied the concentration of heavy metals in cabbage, lettuce and cauliflower grown on urban waste dump sites. The levels of the two most toxic heavy metals ( $\mathrm{Cd}$ and $\mathrm{Pb}$ ) were far higher in the vegetables than the WHO/FAO recommended values and the 
transfer factors of these two metals were also the highest suggesting that consumption of vegetables grown on such sites could be dangerous to human health. Contact to high levels of contaminants, like heavy metals, can result in unpleasant health effects, and organisms that are higher on the food chain are particularly at risk to bioaccumulative effects [13]. Metals like $\mathrm{Hg}, \mathrm{Cd}, \mathrm{Cr}, \mathrm{Pb}, \mathrm{Ni}, \mathrm{Co}$, and $\mathrm{Zn}$ are highly toxic to both flora and fauna components of the ecosystem [18]. The risk of heavy metal contamination in meat is of great concern for both food safety and human health because of the toxic nature of these metals at relatively minute concentrations [39]. In the present research the values for Co in all body parts were higher in chickens that consumed grains raised with sewage water and the lowest were observed in group of chickens that utilized grains raised with ground water in two experiments conducted in both seasons. Present research values of cobalt in blood and gizzard were higher compared to the values found by Abduljaleel et al. [40] in the blood of chicken and quail. Current research values of $\mathrm{Co}$ in bone, heart, kidney and liver tissues were also higher than the values found by Metcheva et al. [41]. These researchers found concentration of different metals $(\mathrm{Pb}, \mathrm{Cd}$, $\mathrm{Cu}, \mathrm{Co}, \mathrm{Mn}$ and $\mathrm{Co}$ ) in various body parts of brown skua (Catharacta lonnbergi), gentoo penguin (Pygoscelis papua) and in crabeater seal (Lobodon carcinophagus). The values may be higher due to the presence of a considerable amount of cobalt in the grains utilized by the chickens. Generally, birds get heavy metals via intake of food, drinking, and geophagy. The extent of heavy metal absorption varies and depending on many factors like species physiology, bioavailability and metal properties, in the environment. After absorption, metals circulate in the body, are excreted or get deposited in various body tissues [42].

The target hazard quotient (THQ) used for assessing health risk and in present research. THQ values of Co for meat, liver and gizzard were less than 1 and these values indicated that exposed population is unlikely to experience obvious adverse effects on utilization of these poultry edibles.

Table 5. Health Risk Estimate for Co ingestion from chicken breast muscle and viscera (liver and gizzard) of Experiment 1 (Spring season) and Experiment 2 (Autumn season)

\begin{tabular}{|c|c|c|c|c|c|c|c|}
\hline \multirow{2}{*}{ Groups of chicken } & \multirow{2}{*}{$\begin{array}{c}\text { Level of } \\
\text { Exposure } \\
\text { day/week }\end{array}$} & \multicolumn{2}{|c|}{$\begin{array}{c}\text { THQ values for breast } \\
\text { muscle }\end{array}$} & \multicolumn{2}{c|}{ THQ values for liver } & \multicolumn{2}{|c|}{$\begin{array}{c}\text { THQ values for } \\
\text { gizzard }\end{array}$} \\
\cline { 3 - 9 } & & E-1 & E-2 & E-1 & E-2 & E-1 & E-2 \\
\hline CFV-1 (GWT) & 7 & 0.067 & 0.006 & 0.080 & 0.015 & 0.089 & 0.033 \\
\hline CFV-1 (SWT) & 7 & 0.070 & 0.007 & 0.084 & 0.015 & 0.081 & 0.036 \\
\hline CFV-1 (CWT) & 7 & 0.069 & 0.006 & 0.082 & 0.017 & 0.073 & 0.034 \\
\hline CFV-2 (GWT) & 7 & 0.069 & 0.007 & 0.090 & 0.016 & 0.072 & 0.033 \\
\hline CFV-2 (SWT) & 7 & 0.074 & 0.012 & 0.096 & 0.020 & 0.084 & 0.037 \\
\hline CFV-2 (CWT) & 7 & 0.074 & 0.010 & 0.090 & 0.019 & 0.078 & 0.035 \\
\hline CFV-3 (GWT) & 7 & 0.075 & 0.011 & 0.092 & 0.020 & 0.067 & 0.035 \\
\hline CFV-3 (SWT) & 7 & 0.076 & 0.013 & 0.096 & 0.025 & 0.056 & 0.037 \\
\hline CFV-3 (CWT) & 7 & 0.075 & 0.013 & 0.093 & 0.022 & 0.057 & 0.036 \\
\hline CFV-4 (GWT) & 7 & 0.079 & 0.014 & 0.092 & 0.023 & 0.056 & 0.035 \\
\hline CFV-4 (SWT) & 7 & 0.084 & 0.017 & 0.096 & 0.025 & 0.060 & 0.037 \\
\hline CFV-4 (CWT) & 7 & 0.082 & 0.016 & 0.093 & 0.024 & 0.070 & 0.036 \\
\hline
\end{tabular}

Key; CFV1, Chicken feed on 'Pearl variety'; CFV2, Chicken feed on 'Sahiwal 2002' variety; CFV3, Chicken feed on 'MMRI' variety; CFV4, Chicken feed on 'Sadaf' variety. GWT (ground water treatment), SWT (sewage water treatment), CWT (canal water treatment 


\section{Ethics}

All the study protocols were approved by the Institutional Animal Ethics Committee, University of Sargodha (Approval No.25A18 IEC UOS). All the experiments performed complied with the rules of the National Research Council [43] and all methods were performed in accordance with relevant guidelines and regulations.

\section{Conclusion}

Irrigation with polluted water may contaminate the food chain with heavy metals. The concentration of cobalt in grains of four varieties of maize was found within the permissible limit given by FAO/WHO. A linear increase in cobalt concentration was observed in seven body parts of the chickens that consumed sewage water raised grains as the concentration of cobalt were higher in these grains compared to the groups that utilized canal water and ground water treated grains in their diet. Target hazard quotient values for cobalt were less than 1.0 for meat, liver and gizzard indicating that utilization of these poultry edibles is safe.

\section{Authors' contributions}

Conceived and designed the experiments: ZI Khan, Performed the experiments: ZE Huma, Analyzed the data: IR Noorka, Contributed reagents/ materials/ analysis tools: K Ahmad \& M Nadeem, Wrote the paper: I Ugulu

\section{Acknowledgement}

The Higher Education Commission, Pakistan is hereby acknowledged for providing the financial support through a research project \# 203546/NRPU/R\&D/HEC/14/536 titled "Toxicological Risk Assessment of Potential Pollutants on Fauna and Flora in Selected Areas of Punjab".

\section{References}

1. Ugulu I (2015). Determination of heavy metal accumulation in plant samples by spectrometric techniques in Turkey. Appl Spectros Rev 50(2): 113151.

2. Khan ZI, Ugulu I, Umar S, Ahmad K, Mehmood N, Ashfaq A, Bashir H \&
Sohail M (2018). Potential toxic metal accumulation in soil, forage and blood plasma of buffaloes sampled from Jhang, Pakistan. Bull Environ Contam Toxicol 101: 235-242 (2018).

3. Dogan Y, Baslar S \& Ugulu I (2014). Astudy on detecting heavy metal accumulation through biomonitoring: Content of trace elements in plants at Mount Kazdagi in Turkey. Appl Ecol Environ Res 12(3): 627-636.

4. Unver MC, Ugulu I, Durkan N, Baslar S \& Dogan Y (2015). Heavy metal contents of Malva sylvestris sold as edible greens in the local markets of Izmir. Ekoloji 24(96): 13-25.

5. Yorek N, Ugulu I \& Aydin H (2016). Using self-organizing neural network map combined with ward's clustering algorithm for visualization of students' cognitive structural models about aliveness concept. Computational Intelligence and Neuroscience, Article ID 2476256: 1-14.

6. Ugulu I, Unver MC. \& Dogan Y (2016). Determination and comparison of heavy metal accumulation level of Ficus carica bark and leaf samples in Artvin, Turkey. Oxid Commun 39(1): 765-775.

7. Dogan Y, Unver MC, Ugulu I, Calis M \& Durkan N (2014). Heavy metal accumulation in the bark and leaves of Juglans regia planted in Artvin City, Turkey. Biotech Biotechnol Equip 28(4): 643-649.

8. McIntyre T (2003). Phytoremediation of heavy metals from soils. $A d v$. Biochem Eng Biotech 78: 97-123.

9. Ahmad K, Nawaz K, Khan ZI, Nadeem M, Wajid K, et al. (2018). Effect of diverse regimes of irrigation on metals accumulation in wheat crop: An assessment-dire need of the day. Fresen Environ Bull 27(2): 846-855.

10. Shen $\mathrm{Z}$, Wang $\mathrm{C}$, Chen $\mathrm{H}$ \& Chua $\mathrm{H}$ (2002). Lead phytoextraction from contaminated soil with high biomass plant species. J Environ Qual 31(6): 1893-1900 (2002). 
11. Ugulu I (2015). Development and validation of an instrument for assessing attitudes of high school students about recycling. Environ Educ Res 21(6): 916-942.

12. Ugulu I (2015). A quantitative investigation on recycling attitudes of gifted/talented students. Biotech Biotechnol Equip 29: 20-26.

13. Khan ZI, Ugulu I, Sahira S, Ahmad K, Ashfaq A, Mehmood N \& Dogan Y (2018). Determination of Toxic Metals in Fruits of Abelmoschus esculentus Grown in Contaminated Soils with Different Irrigation Sources by Spectroscopic Method. Inter J Environ Res 12: 503-511.

14. Madrid L, Barrientos ED \& Madrid F (2002). Distribution of heavy metals contents of urban soils in parks of Seville. Chemosphere 49: 1301-1308.

15. Mapanda F, Mangwayana EN, Nyamangara J \& Giller KE (2005). The effect of long-term irrigation using wastewater on heavy metal contents of soils under vegetables in Harare, Zimbabwe. Agric Ecosys Environ 107 (2-3), 151-165.

16. Durkan N, Ugulu I, Unver MC, Dogan Y \& Baslar S (2011). Concentrations of trace elements aluminum, boron, cobalt and tin in various wild edible mushroom species from Buyuk Menderes River Basin of Turkey by ICP-OES. Trace Elements and Electrolytes 28(4): 242-248.

17. Ugulu I \& Baslar S (2010). The determination and fidelity level of medicinal plants used to make traditional Turkish salves. J Alternative Compl Med 16(3): 313-322.

18. Ugulu I, Dogan Y, Baslar S \& Varol O (2012). Biomonitoring of trace element accumulation in plants growing at Murat Mountain. Int $J$ Environ Sci Tech 9: 527-534.

19. DiMello JPF (2003). Food Safety: Contaminants and Toxins. London: Oxford University Press.
20. Sabir SM, Khan SW \& Hayat I (2003). Effect of environmental pollution on quality of meat in district Bagh, Azad Kashmir. Pakistan J Nutr 2(2): 98-101.

21. Scheuhammer AM (1987). The chronic toxicity Aluminium, Cadmium, Mercury and Lead in birds: A Review. Environ Pollut 46263.

22. Zhuang P, Zou B, Li NY \& Li ZA (2009). Heavy metal contamination in soils and food crops around Dabaoshan mine in Guangdong, China: implication for human health. Environ Geochem Health 31(6), 707-715.

23. Radojevic M \& Bashkin VN (1999). Practical Environmental Analysis. The Royal Society of Chemistry, Cambridge, p. 466.

24. Vukadinovic V \& Bertic B (1988). Book on Agro chemistry and Plant Nutrition. University J.J. Strossmayer in Osijek, Faculty of Agriculture (in Croatian). Osijek, Croatia. p. 56.

25. Anar J, Milai R, Straar M \& Burica O (2000). Total metal concentrations and partitioning of $\mathrm{Cd}, \mathrm{Cr}, \mathrm{Cu}, \mathrm{Fe}, \mathrm{Ni}$ and $\mathrm{Zn}$ in sewage sludge. Sci Total Environ. 250(1-3): 9-19.

26. Mohammed AI, Koloand B \& Geidam YA (2013). Heavy metals in selected tissues of adult chicken layers (Gallus spp). ARPN J Sci Tech 3(5): 518-522.

27. Memon AR, Tasneem GK, Hassan IA \& Nasreen S (2007). Evaluation of Zinc status in whole blood and scalp hair of female cancer patients, Clinica Chimica Acta 379(1-2): 66-70.

28. USEPA (1989). Guidance manual for assessing human health risks from chemically contaminated, fish and shellfish, U.S. Environmental Protection Agency, Washington, D.C. EPA-503/8-89-002.

29. Al-Omran M (2010). Long term effect of irrigation with the treated sewage effluent on some soil properties for date palms in Al Hassa, Saudi Arabia. World Congress of Soil Science, 170172. 
30. Shad HA, Khan ZI, Ahmad K, Rizwan Y \& Tahir HM (2014). Human health hazards caused by heavy metals accumulation in wheat Variety "Sehar2006" irrigated with domestic sewage water. Biologia (Pakistan), 60(1): 99102.

31. Khan ZI, Ahmad K, Ashraf M, Parveen R, Mustafa I, Khan A, Bibi Z \& Akram NA (2015). Bioaccumulation of heavy metals and metalloids in luffa (luffa cylindrical.) irrigated with domestic wastewater in Jhang, Pakistan: A prospect for human nutrition. PakJ Bot 47(1): 217-224.

32. Mojiri A \& Hamidi AA (2011). Effects of municipal wastewater on accumulation of heavy metals in soil and wheat (Triticum aestivum L.) with two irrigation methods. Romanian Agric Res 28: 217-222.

33. Jayakumar K \& Jaleel CA (2009). Uptake and accumulation of cobalt in plants: a study based on exogenous cobalt in soybean. Bot Res Int 2(4): 310-314.

34. Hussain J, Rabbani I, Aslam S \& Ahmad HA (2015). An overview of poultry industry in Pakistan. World's Poultry Sci J 71(4): 689-700.

35. Brar MS, Mahli SS, Singh, AP Arora CL \& Gill KS (2000), Sewage water irrigation effects on some potentially toxic trace elements in soils and potato plants in North Western India. Canadian J Soil Sci 80: 465-471.

36. Tegegne WA (2015). Assessment of some heavy metals concentrations in selected cereals collected from local markets of Ambo city, Ethiopia. $J$ Cereals Oil Seeds 6(2): 8-13.
37. Amin N, Hussain A, Alamzeband S \& Begum S (2013). Accumulation of heavy metals in edible parts of vegetables irrigated with wastewater and their daily intake to adults and children, District Mardan, Pak. Food Chem. 136(3-4): 1515-1523.

38. Odai SN, Mensah E, Sipitey D, Ryo S \& Awuah E (2008). Heavy metals uptake by vegetables cultivated on urban waste dumpsites: Case study of Kumasi, Ghana. Res J Environ Toxicol 2(2): 92-99.

39. Santhi D, Balakrishnan V, Kalaikannan A \& Radhakrishnan KT (2008). Presence of heavy metals in pork products in Chennai (India). Am J Food Tech 3(3): 192-199.

40. Abduljaleel AS (2014). Bioaccumulation of trace elements in tissues of chicken and quail and estimate health risks from the consumption of birds viscera. Basrah J Vet Res 1(2): 95-111 (2014).

41. Metcheva R, Yurukova L, Bezrukov V, Beltcheva M, Yankov Y \& Dimitrov K (2010). Trace and Toxic Elements Accumulation in Food Chain Representatives at Livingston Island (Antarctica). Int J Biol 2(1): 155-161.

42. Furness RW, Muirhead SJ \& Woodburn M (1986). Using bird feathers to measure mercury in the environment: relationship between mercury content and moult. Mar Pollut Bull 17(1): 27-30.

43. National Research Council (1996). Guide for the care and use of laboratory animals. Washington, DC, National Academy Press. 